\title{
Research of Temperature and Moisture during Sitting on Office Chairs
}

\section{Istraživanje temperature i vlage pri sjedenju na uredskim radnim stolicama}

\author{
Original scientific paper • Izvorni znanstveni rad \\ Received-prispjelo: 22. 12. 2011. \\ Accepted-prihvaćeno: 16. 5. 2012. \\ UDK: $630 * 836 ; 674.23$ \\ doi:10.5552/drind.2012.1139
}

\begin{abstract}
When using an office chair, a person comes into direct contact with the seat, where the contact surface creates a microclimate that affects the person's positive or negative mood, depending on temperature and humidity. Relative to temperature and moisture, this microclimate may produce either a positive or a negative effect on a seated person. Foam based padding of seats and backrests have upholstery with insulating properties that prevent the escape of bodily heat and moisture. The present work, carried out with six subjects, was aimed at studying temperature and moisture as the contributing factors to sitting comfort during performance of usual tasks under controlled conditions. The study method employed temperature and moisture measurements on five different office chairs using the probes placed on or in the seats. The statistically evaluated results of objective measurements show significant differences in distribution of temperature and moisture among the tested seats and through different layers of padding materials and upholstery of individual seats. Generally, it may be concluded that the temperature on the seat surface is always higher than inside the seat. On the other hand, humidity is always lower on the seat surface. Temperature and moisture on the surface of moulded foam seats are higher than on other kinds of seats.
\end{abstract}

Keywords: office chair, seating, comfort, temperature, moisture, PU-foam, design, constructions.

SAŽETAK • Pri uporabi uredskoga radnog stolca korisnik dolazi u neposredan dodir sa sjedalom na čijoj se kontaktnoj površini stvara mikroklima koja utječe na čovjekovo pozitivno ili negativno raspoloženje, ovisno o temperaturi i vlazi. Sjedala i nasloni uredskih stolaca obloženi su materijalima prevučenim preko spužvastog ojastučenja koje ima izolirajuća svojstva, čime se sprječava odvođenje topline i vlage od tijela. U radu su istraživane temperatura $i$ vlaga kao činitelji udobnosti sjedenja šest ispitanika na uredskim radnim stolcima za vrijeme obavljanja uobičajenih radnih zadataka u kontroliranim uvjetima. Istraživanje je provedeno metodom mjerenja temperature $i$ vlage na pet različitih konstrukcija sjedala uredskih stolaca uz pomoć mjernih sondi ugrađenih na sjedalo ili u njega. Statistički obrađeni rezultati objektivnih mjerenja temperature i vlage pokazali su da postoje značajne razlike u distribuciji temperature i vlage kroz različite slojeve materijala i presvlaka između sjedala i unutar pojedinog sjedala. Opći je zaključak da je temperatura na površini sjedala uvijek viša od one u njegovoj unutrašnjosti, a vlaga je na površini sjedala uvijek niža od vlage u unutrašnjosti sjedala. Na sjedalu od hladno lijevane spužve temperatura i vlaga na njegovoj površini više su u usporedbi s drugim konstrukcijama sjedala.

Ključne riječi: uredski radni stolac, sjedenje, udobnost, temperatura, vlaga, PU spužva, konstrukcije

\footnotetext{
Authors are assistant, assistant and professor at Faculty of Forestry, University of Zagreb, Zagreb, Croatia.

Autori su asistent, asistentica i profesor Šumarskog fakulteta Sveučilišta u Zagrebu, Zagreb, Hrvatska.
} 


\section{INTRODUCTION}

\section{UVOD}

When sitting on an office chair, the body emits heat and moisture in the surrounding area and, depending on the body-seat contact area, these changes are higher or lower. Thermal comfort of a posture depends on the body and its environment, which is related to the size of a body surface available for temperature exchange (Raja and Nicol, 1997). Metabolism causes continuous radiation of heat and moisture. Consequently, perception of comfort depends on equilibrium between the receipt and release of heat and moisture at the contact point of the body and base (Hänel et al, 1997). As shown by Zacharkow (1988), the resistance to changes is highly related to the size of contact area and contact pressure. Accordingly, the feeling of comfort is connected with the parameters such as pressure, temperature and relative humidity at the contact point of the body and base (quote in: Hänel et al, 1997). According to Hänel et al. (1997) a mechanical component of comfort, the so called "mechanical comfort" is defined as a part of the overall comfort, which depends on distribution of a contact pressure on human body in the seat contact area. The value of contact pressure, its distribution and duration of action are the main factors of "mechanical comfort". Due to scarcity of research into office chairs, the examples from automotive industry can be used to show that thermal comfort is an important factor in ergonomic evaluation of car seats. Upholstery is one of the key factors that determine thermal comfort. Amongst other properties, upholstery must be airy and ensure transport of moisture (Cengiz and Babalık, 2009). Usually foam padding of a seat and a backrest of office chairs is covered by upholstery with insulating properties, which prevents the escape of heat from the body (Bartels 2003). Study results of Nicholson et al. (1999) show to what extent foam inhibits the transfer of heat, and that upholstery limits moisture evaporation. The resistance of invisible (latent) heat loss through upholstery also limits heat transfer. Foam padding impedes transfer of moisture from skin surface, too. The study by Diebschlag (1988) shows that permeability of foam depends not only on its composition but also on pressure. This suggests that thermal comfort varies for different people who use the same task chair, relevant to where and how long they exert pressure on the foam padding of seats and backrests (quotation in: Stumpf et al, 2002). In their study of different padding materials for wheelchairs, Fisher et al. (1978) found significant increase in the skin temperature under thighs and sitting bones of test subjects using $10 \mathrm{~cm}$ thick foam rubber pads (quotation in: Stumpf et al, 2002).

Different standards specify the requirements in thermal comfort (e.g. ISO 7730). However, the responses to indoor thermal environment can vary due to nonenvironmental factors such as different clothing, the difference in the level of activity, individual preferences to temperature and others. Studies have shown that indoor thermal conditions may affect the complaints, di- straction and employee productivity. When using an office chair, a person comes into direct contact with a seat, on which the contact area creates a microclimate that affects the person's positive or negative mood, depending on temperature and humidity (Grbac, 1988). Some scientists investigated the effects under laboratory conditions: Pepler and Warner (1968) examined 36 male and 36 female students in an air-conditioned room and found out that at $26.7^{\circ} \mathrm{C}$ they required more time to complete a task than at $20^{\circ} \mathrm{C}$, although lower prevalence of errors was at $26.7^{\circ} \mathrm{C}$; Fang et al. (2002) investigated the influence of several combinations of temperature and relative humidity on performance of simulated office tasks in 30 female subjects exposed to different combinations of temperature and relative humidity over approximately five hours. The results showed that there was no significant difference in performance of the tasks at higher and lower temperature/humidity combinations (quotation in: Hedge et al, 2005).

Human body maintains the temperature from 36 to $37^{\circ} \mathrm{C}$. Due to constant evaporation of moisture, the temperature on the body surface is around $34^{\circ} \mathrm{C}$ (Brezigar, 1984, quotation in: Grbac, 1988). Our body continually delivers its heat to the environment. If delivery and conduction are too fast, one feels cold, but if it is too slow or if there is no exchange at all, one is hot. Upholstered products have thermal insulation, which is crucial for our life. This insulation depends on fabrics and other materials built into a product. Moisture absorption and heat conduction are interrelated and interdependent: a dry material is a better insulator than a wet one, and moisture absorption is better and faster at higher temperatures. The same is with the delivery of moisture - at higher temperature it is faster and its volume is bigger. Fabrics are better heat conductor than air, whereas air is a good insulator if trapped between two layers of upholstery (Grbac and Dalbelo-Bašić, 1996). In the view of the fact that office chairs are used for almost eight hours a day, it is important that they be constructed with the materials with very high moistureabsorbing and moisture-delivering capacity, relevant to perspiration of a seated person. Under normal conditions during one hour a person perspires 15-32 $\mathrm{g}$ of sweat per body square meter, whereas at the increased ambient temperatures or during the increased physical strain perspiration exceeds $100 \mathrm{~g} / \mathrm{m}^{2}$ (Grbac, 2006; Grbac and Domljan, 2007).

To date researches have shown that the maximum thermal comfort is achieved at the mean skin temperature of around $33.5{ }^{\circ} \mathrm{C}$ (Arens et al, 2006; Sakoi et al, 2007). In the study of Cengiz and Babalık (2009) it has been confirmed that upholstery in cars influenced thermal comfort and that the mean skin temperature ranged between 33.31 and $35.89{ }^{\circ} \mathrm{C}$. Moreover, the area around the waist was found to be the most important one in determining perception of thermal comfort, whereas local thermal discomfort was particularly high on the back (Sakoi et al, 2007).

Measurements of physical properties of upholstering (e.g. determination of water vapour permeability) show that at the beginning permeability increases with 


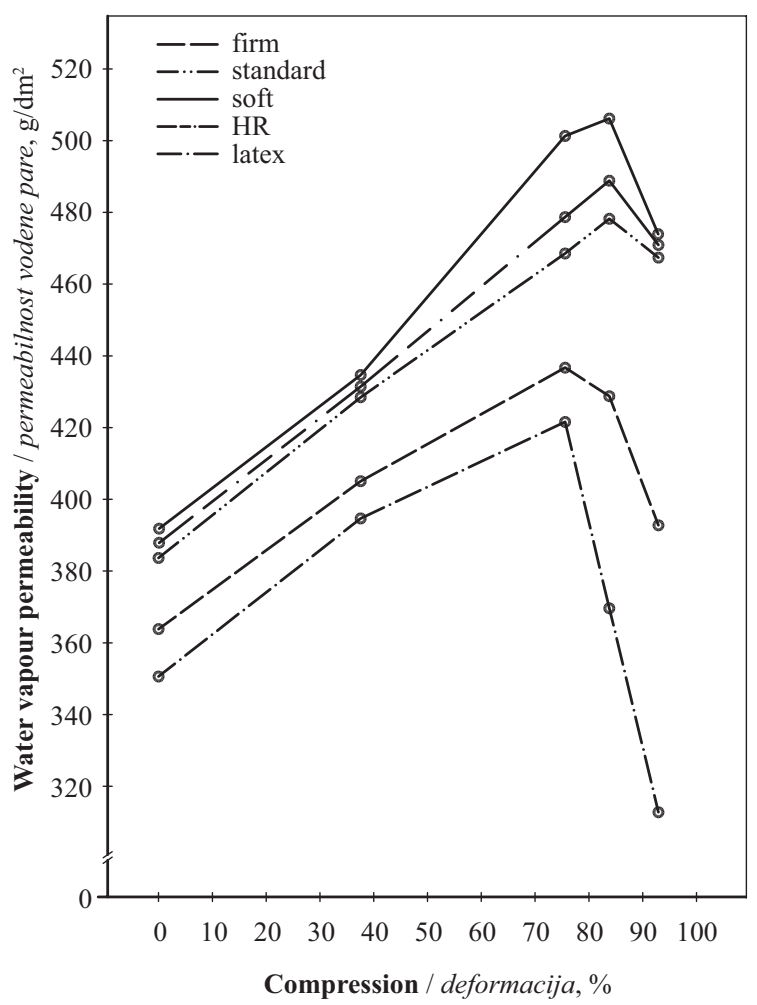

Figure 1 Permeability for humidity of different PU-foams vs. relative compression (source: Kurz et al, 1989)

Slika 1. Permeabilnost vlage različitih PU spužvi u odnosu prema relativnoj deformaciji (izvor: Kurz i sur., 1989)

increased compressing of the upholstering, due to smaller diffusion distance. Only after compression of $75-85 \%$ of the original thickness, due to its increasing density, water vapour permeability is reduced (Figure 1) (Kurz et al, 1989). This interdependence points out how important it is that seats and backrests are permeable to water vapour in order to allow escape (evaporation) of moisture from upholstering materials.

Ick et al. (1976) studied the use of flexible PU-foams in car seats and showed that heat conductivity of PU-foams ranged between 0.04 and $0.05 \mathrm{~W} / \mathrm{m} \cdot \mathrm{K}$ (at $15 \%$ compression), which depended on the cellular foam cell structure. Estimates of heat produced during drive show that minimal conductivity of $50 \mathrm{~mm}$ and 100 $\mathrm{mm}$ padding should be $0.11 \mathrm{~W} / \mathrm{m} \cdot \mathrm{K}$ and $0.21 \mathrm{~W} / \mathrm{m} \cdot \mathrm{K}$, respectively, whereas the aimed dissipation of sufficient heat must be vertical through the padding material. If this is not possible, the temperature in a seat goes up to $37^{\circ} \mathrm{C}$ and perspiration is very high. If the evaporated water is not released sufficiently fast, it condenses on the sitting area and this is a definitely unwelcome and unpleasant effect. Practical tests and subjects' opinion show that with PU upholstering sufficient volume of water vapour and heat are transferred horizontally (instead of vertically) from the sitting area, which ensures maintenance of comfortable sitting climate. The volume of this horizontal transport of moisture is mainly determined by the composition of users' clothes and quality of seats' upholstery. In addition, changing of sitting posture provides additional air cooling.

Ideal humidity at the skin-surface contact point is $40-65 \%$ RH. Contact temperature should not change for more than several degrees (Cochran and Palmieri, 1980; quotation in: Nicholson et al, 1999). Clinical estimates show that relative humidity measured under the thighs during sitting is between $40 \%$ and $100 \% \mathrm{RH}$, and that the temperature under sitting bones varies between 30 ${ }^{\circ} \mathrm{C}$ and the body temperature. Heat flow from the skin varies during posture change from -9 to $+106 \mathrm{~W} / \mathrm{m}^{2}$. When it comes to car seats or beds, for enjoying comfort under hot microclimate conditions, it is necessary to ensure sufficient moisture drain capacity from the contact point. Hänel et al. (1997) showed that thermal behaviour of an upholstered chair depends mainly on thermal properties of the upper layer, i.e. the one that is in contact with the body. Constructional variations of the supporting part of a seat did not present any significant improvement. In his research of quality and comfort of lying, Grbac (1988) obtained much the same results related to the importance of the upper layer for human health and for providing sitting and laying comfort.

Figure 2 shows resistance of two different fabrics and of a plastic sheet not permeable to moisture transfer. As is the case with temperature, it can be concluded about moisture, too, that the top layer is most important for the feeling of comfort (Hänel et al. 1997; Qian and Fan, 2006). According to Bartels (2003), for physiological comfort of a chair, thermal insulation is usually less important than moisture transfer. Good moisture absorbents are natural fibres, coconut fibres, wool and cotton. On the other hand, synthetic materials such as polyesters, polypropylene, PU-foam and polyamide are poor moisture absorbents (Grbac and Ivelić, 2005; Vlaović et al, 2006). Grbac and Dalbelo-Bašić (1996) have confirmed that the materials used to produce a decorative and upper layer of mattresses are crucial for sleeping thermophysiology but natural construction materials should be given the preference.

The aim of this study was to detect the flow passage of heat and moisture that passes from a seat surface to its interior through upholstery and PU-foam of different characteristics during the sitting of users, i.e. to determine the conductivity of these materials. The goal was to determine the capability of the equipment for determination of thermophysiological characteristics of sitting by temperature and humidity measurements, and to detect occurrence of heat and moisture on the seat surface and interior during sitting.

\section{MATERIAL AND METHODS} 2. MATERIJAL I METODE

The research method applied temperature and humidity measurements with the probes supplied with two corresponding sensors in one housing (Figure 3a). Data were collected by electronic device $H O B O^{\circledR}$ Weather Station H21-001 (Onset Computer Corporation, USA) and data processing was performed with $\mathrm{HOBO}$ ware Pro ver. 2.7.3. and SPSS ver. 13.0 software.

The probes were positioned in two ways (Vlaović, 2009): into the seats and on the surface, just above the "interior" probes, and then fixed with the adhesive (Figures $3 b$ and $3 c$ ). 


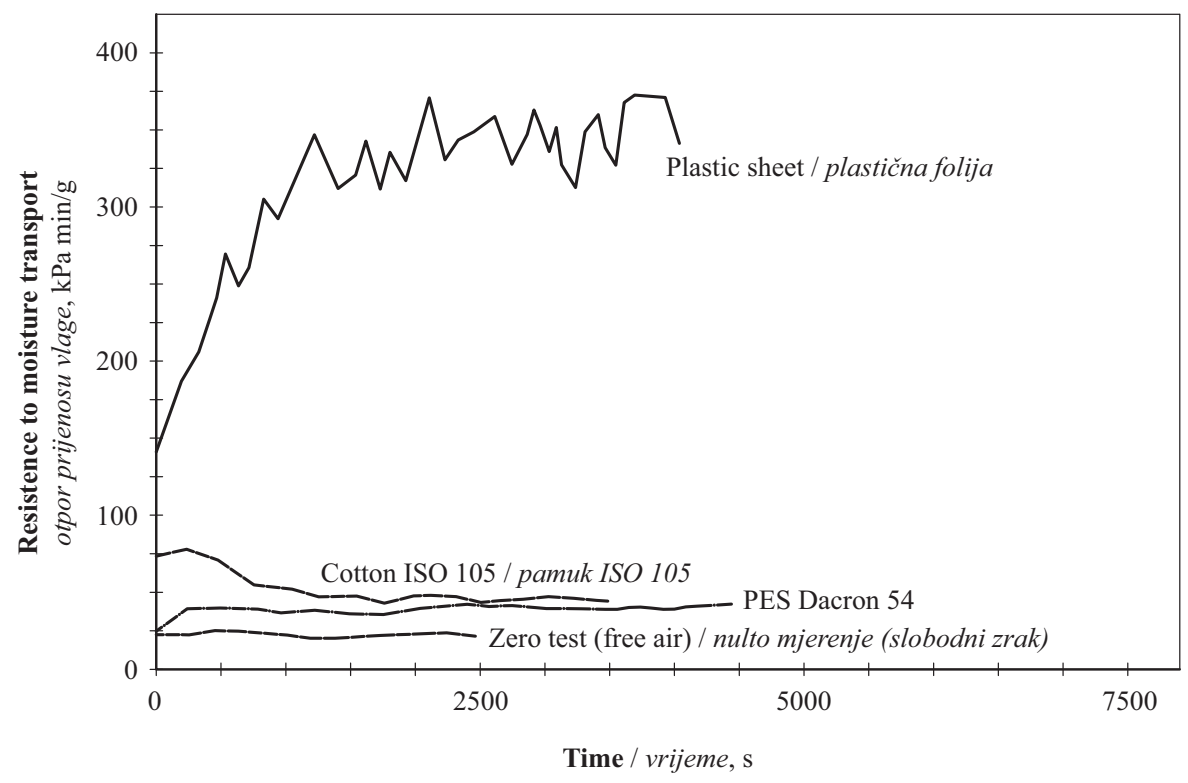

Figure 2 Resistance to moisture transport measured with the IFP indenter (source: Hänel i sur. 1997) Slika 2. Otpor prijenosu vlage mjeren uz pomoć IFP indentora (izvor: Hänel i sur., 1997)

There were six probes in total (three on the seat, two in the seat and one in the room), placed at four measurement points (A, B, C and D):

- Measuring point A covered the area under the gluteus (buttocks) around the sitting bone of the left lower extremity on the seat surface (probe 1-A) and in the seat (probe 2-A);

- Measuring point B covered the area under the left thigh on the seat surface (probe 3-B) and in the seat (probe 4-B);

- Measuring point $\mathrm{C}$ covered the area between the lower extremities in the centre of the seat surface (probe 5-C);

- Measuring point D covered the area behind the backrest (probe 6-D) to monitor room conditions.

Due to sitting and compression of the PU-foam, the probes in the seats were partially pushed out. On the underside of the seats the probes had been fixed with the adhesive, which also closed the holes with the probes, thus preventing the escape/entry of moisture and heat. Given the size and position of the built in probes, we can say that temperature and moisture were measured in the central and lower layer of the seat upholstering.

Measurements were carried out in the air-conditioned room, at the mean temperature of $23.94^{\circ} \mathrm{C}$ and relative humidity of $46.43 \%$ throughout six days. In order to minimize the influence of clothing, the subjects were wearing cotton underwear and light linen or cotton clothing. According to the pre-determined schedule, six subjects were tested on five selected chairs, using two chairs per day, each during 90 minutes. Minimal suspension time between two measurements was 10 minutes. Sampling frequency was one per minute. Every sample contained the information on temperature and relative humidity (6 of each). Prior to the measurement, the height of the seats and armrests had been tuned to every subject in order to ensure maximum comfort, all in accordance with the table height, as required by the corresponding basic ergonomic criteria.

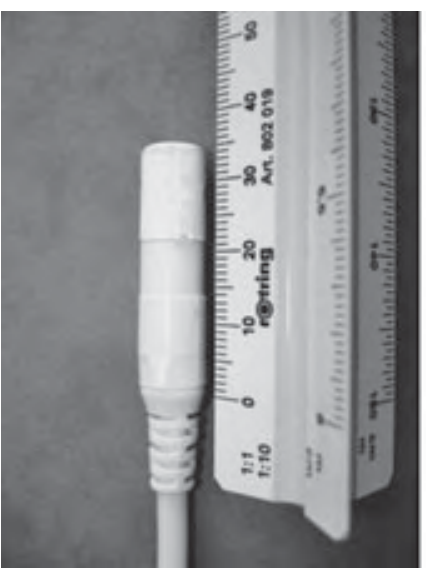

a) The probe / Mjerna sonda

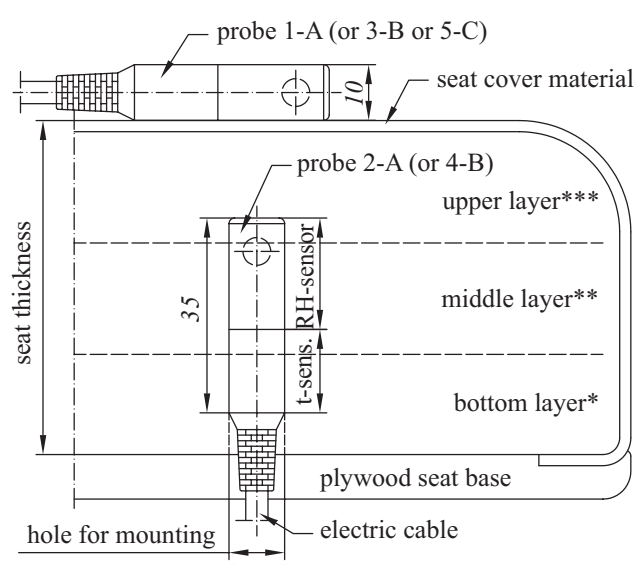

b) Probes installation on/in the unloaded seat / Shematski prikaz ugradnje sonde na/u neopteréeno sjedalo

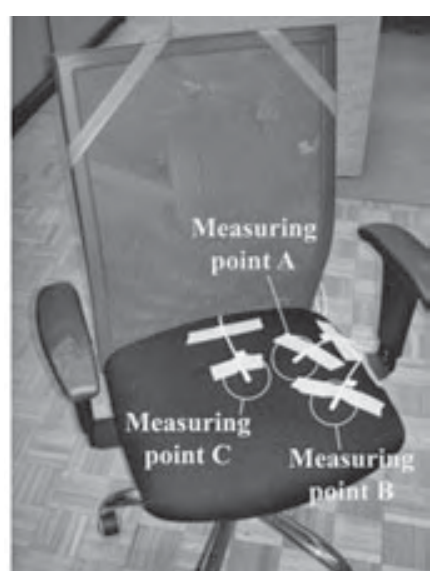

c) Probes on the seat / Sonde postavljene na sjedalo

Figure 3 Measurement probe (S-THB-M008) and installation

Slika 3. Mjerna sonda (S-THB-M008) i način njezine ugradnje 

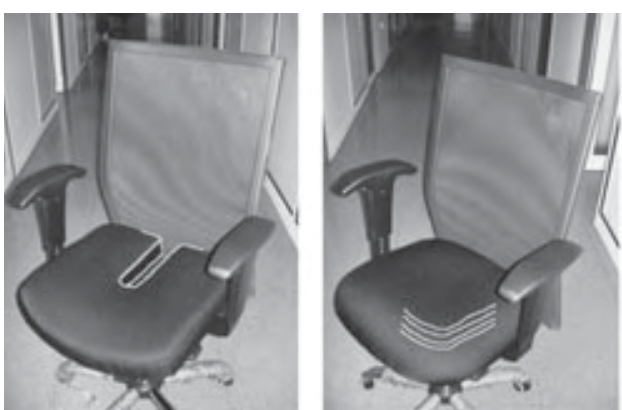

b) Model M2

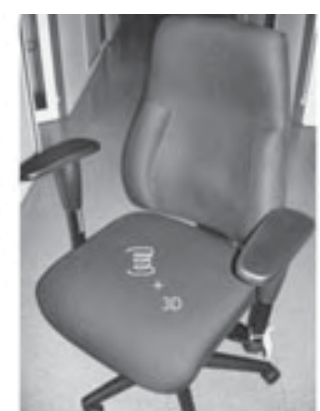

c) Model M3

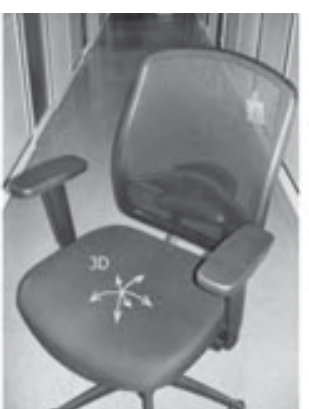

d) Model M4

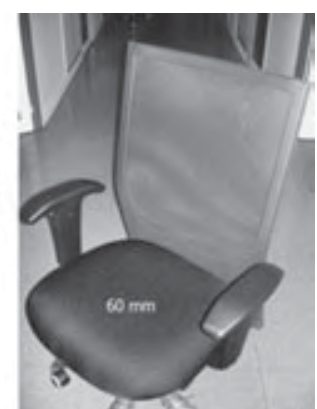

e) Model M5

Figure 4 Samples of office chairs

Slika 4. Uzorci uredskih radnih stolaca

Table 1 Seat characteristics of office chair models

Tablica 1. Svojstva sjedala modela uredskih stolica

\begin{tabular}{|c|c|c|c|c|c|}
\hline Model & M1 & M2 & M3 & M4 & M5 \\
\hline $\begin{array}{l}\text { Seat characteristic } \\
\text { značajka } \\
\text { sjedala }\end{array}$ & $\begin{array}{l}\text { A notch for coccyx } \\
\text { and prostate, } \\
\text { PU 2-layer } \\
\text { urez za trticu i } \\
\text { prostatu, } \\
\text { dvoslojni PU }\end{array}$ & $\begin{array}{l}\text { PU 3-layer } \\
\text { troslojni PU }\end{array}$ & $\begin{array}{l}\text { More suited to female, } \\
\text { mobile in } 3 \mathrm{D}, \mathrm{PU} \\
\text { 2-layer } \\
\text { prikladnije za žene, } \\
\text { gibljivo u } 3 D \\
\text { dvoslojno }\end{array}$ & $\begin{array}{l}\text { Mobile in all } \\
\text { directions (3D), } \\
\text { PU 1-layer } \\
\text { gibljivo u svim } \\
\text { smjerovima (3D), } \\
\text { jednoslojno }\end{array}$ & $\begin{array}{l}\text { Standard, } \\
\text { PU 1-layer } \\
\text { standardno, } \\
\text { jednoslojni PU }\end{array}$ \\
\hline $\begin{array}{l}\text { Cover material } \\
\text { composition } \\
\text { sastav presvlake }\end{array}$ & $100 \%$ Polyester & $100 \%$ Polyester & $100 \%$ Polyester & $\begin{array}{l}\text { 100\% Polyester } \\
(\text { Trevira } \AA \text { CS })\end{array}$ & $100 \%$ Polyester \\
\hline $\begin{array}{l}\text { Seat construction } \\
\text { konstrukcija } \\
\text { sjedala }\end{array}$ & $\begin{array}{l}\text { Slabstock foams } \\
\text { rezane spužve: } \\
40 \mathrm{~mm} \text { PT3246*** } \\
20 \mathrm{~mm} \text { PG65120* }\end{array}$ & $\begin{array}{l}\text { Slabstock foams } \\
\text { rezane spužve: } \\
20 \mathrm{~mm} \text { VISCO*** } \\
20 \mathrm{~mm} \text { PT3246** } \\
20 \mathrm{~mm} \text { PG65120* }\end{array}$ & \begin{tabular}{|l|} 
Moulded PU-foam \\
hladno lijevana \\
spužva: \\
$10 \mathrm{~mm}$ PU $4040 * * *$ \\
$45 \mathrm{~mm}$ pocket springs \\
džepićaste opruge* \\
$(\mathrm{D} 45 \mathrm{~mm} / \mathrm{r} 1.8 \mathrm{~mm})$
\end{tabular} & $\begin{array}{l}\text { Moulded PU-foam } \\
\text { hladno lijevana } \\
\text { spužva: } \\
55 \text { mm PU } 4040\end{array}$ & $\begin{array}{l}\text { Slabstock foam } \\
\text { rezana spužva: } \\
60 \text { mm PT3246 }\end{array}$ \\
\hline $\begin{array}{l}\text { Total density } \\
\text { ukupna gustoća }\end{array}$ & $41.3 \mathrm{~kg} / \mathrm{m}^{3}$ & $48.5 \mathrm{~kg} / \mathrm{m}^{3}$ & $40 \mathrm{~kg} / \mathrm{m}^{3}$ & $40 \mathrm{~kg} / \mathrm{m}^{3}$ & $28.3 \mathrm{~kg} / \mathrm{m}^{3}$ \\
\hline $\begin{array}{l}\text { Seat thickness } \\
\text { debljina sjedala }\end{array}$ & $60 \mathrm{~mm}$ & $60 \mathrm{~mm}$ & $55 \mathrm{~mm}$ & $55 \mathrm{~mm}$ & $60 \mathrm{~mm}$ \\
\hline
\end{tabular}

\subsection{Samples}

\subsection{Uzorci}

The study used five models of office chairs (Figure 4). The samples were selected according to the principles of proper body support in the working posture and constructions that enable proper and comfortable sitting posture as a pre-condition for comfort (Vlaović et al, 2008, Vlaović et al, 2010). In addition, the attention was paid to compliance of the samples with the current standards regarding functional dimensions. Every sample is detailed in Table 1. All seats were made of non-hygroscopic material.

\subsection{Subjects \\ 2.2. Ispitanici}

The study included healthy females and males ( 3 of each). The subjects' details are given in the following table:
Table 2 Anthropometric characteristics of subjects

Tablica 2. Antropometrijske osobine ispitanika

\begin{tabular}{|l|c|c|c|c|}
\hline \multicolumn{1}{|c|}{$\begin{array}{c}\text { Subjects' code } \\
\text { Oznaka ispitanika }\end{array}$} & $\begin{array}{c}\text { Age, } \\
\text { year } \\
\text { Starost, } \\
\text { godine }\end{array}$ & $\begin{array}{c}\text { Height } \\
\text { Visina, } \\
\mathrm{cm}\end{array}$ & $\begin{array}{c}\text { Mass } \\
\text { Masa, } \\
\mathrm{kg}\end{array}$ & $\begin{array}{c}\text { BMI* } \\
\mathrm{kg} / \mathrm{m}^{2}\end{array}$ \\
\hline Female 1 & 37 & 166 & 61 & 22.1 \\
\hline Female 2 & 43 & 164 & 70 & 26.0 \\
\hline Female 3 & 33 & 166 & 65 & 23.6 \\
\hline Male 4 & 29 & 182 & 68 & 20.5 \\
\hline Male 5 & 34 & 184 & 79 & 23.3 \\
\hline Male 6 & 34 & 181 & 91 & 27.8 \\
\hline Minimum & 29 & 164 & 61 & 20.53 \\
\hline Maximum & 43 & 184 & 91 & 27.78 \\
\hline $\begin{array}{l}\text { Arithmetical mean } \\
\text { aritmetička sredina }\end{array}$ & 35 & 173.8 & 72.33 & 23.90 \\
\hline $\begin{array}{l}\text { Standard deviation } \\
\text { standardna devijacija }\end{array}$ & 4.28 & 8.57 & 9.99 & 2.40 \\
\hline
\end{tabular}

* Body Mass Index / indeks tjelesne mase 


\section{RESULTS AND DISCUSSION}

\section{REZULTATI I DISKUSIJA}

Measurement results for temperature and moisture on/in the studied seats are given as arithmetic means and standard deviations in Table 3. It is clear that the probe 3-B of the M4 model recorded the highest temperature $\left(t_{\max }=35.31^{\circ} \mathrm{C}\right)$, and the probe 2-A of the M5 model the lowest temperature $\left(t_{\min }=24.82^{\circ} \mathrm{C}\right)$. The highest moisture was recorded by the probe $2-\mathrm{A}$ of the M4 model $\left(R H_{\max }=71.88 \%\right)$, and the lowest by the probe 3 -B of the M2 model $\left(R H_{\text {min }}=47.43 \%\right)$.

The analysis of temperature measurements obtained from the probes in the seats (2-A and 4-B) vs. their surface pairs (1-A and 3-B) shows that the seat surface temperature is always higher than the interior temperature of the corresponding seat. In such a temperature gradient, the biggest differences are recorded in the M5 model (gluteal area $\Delta=9.55{ }^{\circ} \mathrm{C}$; thigh area $\Delta=9.48^{\circ} \mathrm{C}$ ), and the smallest in the M1 model (gluteal area $\Delta=8.80^{\circ} \mathrm{C}$; thigh area $\Delta=8.53^{\circ} \mathrm{C}$ ). In other words, the M1 model has better vertical permeability of heat, which should ensure more comfortable sitting because the temperature does not stay only on the surface. With regard to previous findings on the "interior" temperatures, it can be assumed that the M1 seat is a minor thermal insulator and that, under specific ambient conditions, sitting on that chair will be more comfortable.

The analysis of moisture measurements obtained from the probes in the seats (2-A and 4-B) vs. their surface pairs (1-A and 3-B) shows that the seat interior moisture content is always higher than the surface moisture of the corresponding seat. In such a moisture gradient the biggest differences are recorded in the M5 model (gluteal area $\Delta=15.96 \%$; thigh area $\Delta=16.58$ $\%$ ), and the smallest in the M1 model (gluteal area $\Delta=11.25 \%$; thigh area $\Delta=12.56 \%$ ). In other words, the M1 model has better vertical permeability, which should provide more comfort.

Along with the previously described analyses, the obtained results were also compared with the use of the Student's $t$-test for dependent samples. The record- ed temperatures and moisture contents were compared separately as well as their occurrence on the seat surface and interior. Only significant differences are shown (Tables 4 and 5).

The results and their analysis show that (I.) statistically (Table 4) in the gluteal area on the M4 model seat surface, the temperature is significantly higher than on the models M3 $(t=-3.98 ; p=0.011)$ and M5 $(t=2.24$; $p=0.075)$. Inside the M1 seat model, the temperature is significantly higher than in the models M2 $(t=2.55$; $p=0.051), \mathrm{M} 3 \quad(t=2.70 ; p=0.043)$ and M5 $(t=6.12$; $p=0.002$ ), whereas statistically in the M4 seat model, it is significantly higher than in the M3 model $(t=-3.50$; $p=0.017$ ). (II.) Statistically, in the area of thighs on the surface of the M4 seat model, the temperature is significantly higher than on the seat models M2 $(t=-2.52$; $p=0.054), \mathrm{M} 3(t=-4.19 ; p=0.009)$ and M5 $(t=2.65$; $p=0.046)$. Inside the seats the temperature is significantly higher in the M1 model than in the models M2 $(t=3.30 ; p=0.021)$ and M5 $(t=5.14 ; p=0.004)$, and statistically the inside seat temperature of the M4 model is significantly higher than in the M3 model $(t=-2.14$; $p=0.085$ ). (III.) The temperature measurements between lower extremities on the M1 model are significantly lower than on the models M2 $(t=-4.30 ; p=0.008), \mathrm{M} 3(t=$ -5.92; $\mathrm{p}=0.002), \mathrm{M} 4(t=-5.41 ; p=0.003)$ and M5 $(t=$ $-5.20 ; p=0.003)$. This finding is not a surprise with respect to the seat construction of the M1 model, which had a probe slot. However, the temperature on the same place on the M4 seat is significantly higher than on the seat models M2 $(t=-2.17 ; p=0.082)$, M3 ( $t=-4.16$; $p=0.009)$ and $\operatorname{M} 5(t=2.43 ; p=0.060)$.

Moisture content (Table 5) (I.) in the gluteal area on the M4 model seat surface is significantly higher than on the seat models M1 $(t=-4.32 ; p=0.008), \mathrm{M} 2(t=-2.73$; $p=0.041), \mathrm{M} 3(t=-4.91 ; p=0.004)$ and M5 $(t=2.23$; $p=0.077$ ). Relative humidity inside the seat model M4 is significantly higher than in the seats of M1 $(t=-2.70$; $p=0.043)$ and M3 $(t=-2.75 ; p=0.041)$. (II.) Moisture measured in the area of thighs on the seat surface of the M4 model is significantly higher than on the models M1 $(t=$ -7.59; $p=0.001), \mathrm{M} 2(t=-2.89 ; p=0.034)$ and M3 $(t=$

Table 3 Arithmetical mean (and standard deviations) of measured temperature and humidity on/in the seat

Tablica 3. Aritmetičke sredine (i standardne devijacije) izmjerene temperature i vlage u/na sjedalu

\begin{tabular}{|c|c|c|c|c|c|c|c|c|c|c|}
\hline \multirow{2}{*}{$\begin{array}{c}\text { Sample } \\
\text { Uzorak }\end{array}$} & \multicolumn{2}{|c|}{$\begin{array}{c}\text { Probe 1-A } \\
\text { Sonda 1- } A\end{array}$} & \multicolumn{2}{c|}{$\begin{array}{c}\text { Probe 2-A } \\
\text { Sonda 2- } A\end{array}$} & \multicolumn{2}{c|}{$\begin{array}{c}\text { Probe 3-B } \\
\text { Sonda } B\end{array}$} & \multicolumn{2}{c|}{$\begin{array}{c}\text { Probe 4-B } \\
\text { Sonda 4- } B\end{array}$} & \multicolumn{2}{c|}{$\begin{array}{c}\text { Probe 5-C } \\
\text { Sonda 5-C }\end{array}$} \\
\cline { 2 - 12 } & $t,{ }^{\circ} \mathrm{C}$ & $R H, \%$ & $t,{ }^{\circ} \mathrm{C}$ & $R H, \%$ & $t,{ }^{\circ} \mathrm{C}$ & $R H, \%$ & $t,{ }^{\circ} \mathrm{C}$ & $R H, \%$ & $t,{ }^{\circ} \mathrm{C}$ & $R H, \%$ \\
\hline $\mathrm{M} 1$ & 34.52 & 53.01 & 25.72 & 64.26 & 34.42 & 48.06 & 25.89 & 60.62 & 33.50 & 55.30 \\
& $(0.75)$ & $(6.09)$ & $(0.26)$ & $(4.49)$ & $(1.32)$ & $(3.66)$ & $(0.43)$ & $(3.79)$ & $(0.71)$ & $(8.90)$ \\
\hline $\mathrm{M} 2$ & 34.34 & 50.99 & 25.21 & 64.20 & 34.27 & 47.43 & 25.28 & 61.99 & 34.36 & 62.34 \\
& $(0.80)$ & $(5.77)$ & $(0.38)$ & $(5.79)$ & $(0.98)$ & $(4.40)$ & $(0.40)$ & $(5.00)$ & $(0.52)$ & $(12.33)$ \\
\hline $\mathrm{M} 3$ & 33.93 & 50.22 & 24.85 & 65.24 & 34.46 & 47.80 & 25.14 & 61.66 & 34.23 & 57.18 \\
& $(0.69)$ & $(3.57)$ & $(0.81)$ & $(3.34)$ & $(0.50)$ & $(3.88)$ & $(0.81)$ & $(2.57)$ & $(0.52)$ & $(5.61)$ \\
\hline M4 & 34.98 & 58.52 & 25.58 & 71.88 & 35.31 & 51.96 & 25.76 & 66.93 & 35.03 & 68.10 \\
& $(0.26)$ & $(5.54)$ & $(0.52)$ & $(4.38)$ & $(0.27)$ & $(4.31)$ & $(0.39)$ & $(1.57)$ & $(0.50)$ & $(6.87)$ \\
\hline M5 & 34.37 & 51.86 & 24.82 & 67.82 & 34.49 & 49.44 & 25.01 & 66.02 & 34.51 & 65.79 \\
& $(0.48)$ & $(4.96)$ & $(0.48)$ & $(5.00)$ & $(0.72)$ & $(4.66)$ & $(0.60)$ & $(5.53)$ & $(0.41)$ & $(6.21)$ \\
\hline
\end{tabular}

Note: Probe1-A: temperature and moisture under the gluteus on the seat; Probe 2-A: temperature and moisture in the seat under 1-A; Probe 3-B: temperature and moisture under the thigh on the seat; Probe 4-B: temperature and moisture in the seat under 3-B; Probe 5-C: temperature and moisture in the centre of the seat between the lower extremities. / Napomena: Sonda 1-A: temperatura $i$ vlaga ispod gluteusa na sjedalu; sonda 2-A: temperatura $i$ vlaga u sjedalu ispod 1-A; sonda 3-B: temperatura $i$ vlaga ispod natkoljenice na sjedalu; sonda 4-B: temperatura $i$ vlaga u sjedalu ispod 3-B; sonda 5-C: temperatura i vlaga na sredini sjedala između nogu ispitanika. 
Table 4 Results of $t$-test for paired samples for temperature Tablica 4. $T$-test za zavisne uzorke rezultata temperature

\begin{tabular}{|c|c|c|c|c|c|}
\hline $\begin{array}{c}\text { Probe } \\
\text { sonda } \\
1-A\end{array}$ & $\begin{array}{l}\text { Mean } \\
{ }^{\circ} \mathrm{C}\end{array}$ & SEM & $S D$ & $t$-test & $p$ value \\
\hline M3 & 33.93 & 0.282 & 0.690 & \multirow[t]{2}{*}{-3.977} & \multirow[t]{2}{*}{$0.011 *$} \\
\hline M4 & 34.98 & 0.104 & 0.256 & & \\
\hline M4 & 34.98 & 0.104 & 0.256 & \multirow[t]{2}{*}{2.244} & \multirow[t]{2}{*}{$0.075^{* *}$} \\
\hline M5 & 34.37 & 0.196 & 0.481 & & \\
\hline $2-A$ & Mean & SEM & $S D$ & $t$-test & $p$ value \\
\hline M1 & 25.72 & 0.106 & 0.261 & \multirow[t]{2}{*}{2.550} & \multirow[t]{2}{*}{$.051^{* *}$} \\
\hline M2 & 25.21 & 0.155 & 0.380 & & \\
\hline M1 & 25.72 & 0.106 & 0.261 & \multirow[t]{2}{*}{2.701} & \multirow[t]{2}{*}{$.043^{*}$} \\
\hline M3 & 24.85 & 0.330 & 0.808 & & \\
\hline M1 & 25.72 & 0.106 & 0.261 & \multirow[t]{2}{*}{6.123} & \multirow[t]{2}{*}{$.002 *$} \\
\hline M5 & 24.82 & 0.196 & 0.480 & & \\
\hline M3 & 24.85 & 0.330 & 0.808 & \multirow[t]{2}{*}{-3.498} & \multirow[t]{2}{*}{$.017^{*}$} \\
\hline M4 & 25.58 & 0.211 & 0.517 & & \\
\hline $3-B$ & Mean & SEM & $S D$ & $t$-test & $p$ value \\
\hline M2 & 34.27 & 0.401 & 0.982 & \multirow[t]{2}{*}{-2.515} & \multirow[t]{2}{*}{$.054 * *$} \\
\hline M4 & 35.31 & 0.111 & 0.273 & & \\
\hline M3 & 34.46 & 0.205 & 0.503 & \multirow[t]{2}{*}{-4.187} & \multirow[t]{2}{*}{$.009 *$} \\
\hline M4 & 35.31 & 0.111 & 0.273 & & \\
\hline M4 & 35.31 & 0.111 & 0.273 & \multirow[t]{2}{*}{2.646} & \multirow[t]{2}{*}{$.046^{*}$} \\
\hline M5 & 34.49 & 0.295 & 0.722 & & \\
\hline 4-B & Mean & SEM & $S D$ & $t$-test & $p$ value \\
\hline M1 & 25.89 & 0.175 & 0.429 & \multirow[t]{2}{*}{3.301} & \multirow[t]{2}{*}{$.021^{*}$} \\
\hline M2 & 25.28 & 0.162 & 0.396 & & \\
\hline M1 & 25.89 & 0.175 & 0.429 & \multirow[t]{2}{*}{5.144} & \multirow[t]{2}{*}{$.004 *$} \\
\hline M5 & 25.01 & 0.246 & 0.604 & & \\
\hline M3 & 25.14 & 0.330 & 0.809 & \multirow[t]{2}{*}{-2.144} & \multirow[t]{2}{*}{$.085^{* *}$} \\
\hline M4 & 25.76 & 0.161 & 0.394 & & \\
\hline $5-\mathrm{C}$ & Mean & SEM & $S D$ & $t$-test & $p$ value \\
\hline M1 & 33.50 & 0.289 & 0.707 & \multirow[t]{2}{*}{-4.298} & $.008^{*}$ \\
\hline M2 & 34.36 & 0.211 & 0.516 & & \\
\hline M1 & 33.50 & 0.289 & 0.707 & -5.915 & $.002 *$ \\
\hline M3 & 34.23 & 0.213 & 0.521 & & \\
\hline M1 & 33.50 & 0.289 & 0.707 & -5.411 & $.003^{*}$ \\
\hline M4 & 35.03 & 0.205 & 0.501 & & \\
\hline M1 & 33.50 & 0.289 & 0.707 & -5.202 & $.003^{*}$ \\
\hline M5 & 34.51 & 0.165 & 0.405 & & \\
\hline M2 & 34.36 & 0.211 & 0.516 & -2.170 & $.082 * *$ \\
\hline M4 & 35.03 & 0.205 & 0.501 & & \\
\hline M3 & 34.23 & 0.213 & 0.521 & -4.159 & $.009 *$ \\
\hline M4 & 35.03 & 0.205 & 0.501 & & \\
\hline M4 & 35.03 & 0.205 & 0.501 & 2.426 & $.060^{* *}$ \\
\hline M5 & 34.51 & 0.165 & 0.405 & & \\
\hline
\end{tabular}

Table 5 Results of t-test for paired samples for moisture Tablica 5. T-test za zavisne uzorke rezultata vlage

\begin{tabular}{|c|c|c|c|c|c|}
\hline $\begin{array}{c}\text { Probe } \\
\text { sonda } \\
1-A\end{array}$ & Mean $\%$ & SEM & $S D$ & $t$-test & $p$ value \\
\hline M1 & 53.01 & 2.487 & 6.091 & \multirow[t]{2}{*}{-4.324} & \multirow[t]{2}{*}{$.008^{*}$} \\
\hline M4 & 58.52 & 2.263 & 5.543 & & \\
\hline M2 & 50.99 & 2.355 & 5.768 & \multirow[t]{2}{*}{-2.730} & \multirow[t]{2}{*}{$.041^{*}$} \\
\hline M4 & 58.52 & 2.263 & 5.543 & & \\
\hline M3 & 50.22 & 1.457 & 3.570 & \multirow[t]{2}{*}{-4.909} & \multirow[t]{2}{*}{$.004 *$} \\
\hline M4 & 58.52 & 2.263 & 5.543 & & \\
\hline M4 & 58.52 & 2.263 & 5.543 & \multirow[t]{2}{*}{2.226} & \multirow[t]{2}{*}{$.077 * *$} \\
\hline M5 & 51.86 & 2.026 & 4.962 & & \\
\hline $2-\mathrm{A}$ & Mean & SEM & $S D$ & $t$-test & $p$ value \\
\hline M1 & 64.26 & 1.833 & 4.489 & \multirow[t]{2}{*}{-2.700} & \multirow[t]{2}{*}{$.043 *$} \\
\hline M4 & 71.88 & 1.789 & 4.381 & & \\
\hline M3 & 65.24 & 1.362 & 3.336 & \multirow[t]{2}{*}{-2.745} & \multirow[t]{2}{*}{$.041 *$} \\
\hline M4 & 71.88 & 1.789 & 4.381 & & \\
\hline $3-B$ & Mean & SEM & $S D$ & $t$-test & $p$ value \\
\hline M1 & 48.06 & 1.496 & 3.664 & \multirow[t]{2}{*}{-7.588} & \multirow[t]{2}{*}{$.001 *$} \\
\hline M4 & 51.96 & 1.761 & 4.314 & & \\
\hline M2 & 47.43 & 1.796 & 4.399 & \multirow[t]{2}{*}{-2.886} & \multirow[t]{2}{*}{$.034 *$} \\
\hline M4 & 51.96 & 1.761 & 4.314 & & \\
\hline M3 & 47.80 & 1.583 & 3.878 & \multirow[t]{2}{*}{-3.428} & \multirow[t]{2}{*}{$.019 *$} \\
\hline M4 & 51.96 & 1.761 & 4.314 & & \\
\hline 4-B & Mean & SEM & $S D$ & $t$-test & $p$ value \\
\hline M1 & 60.62 & 1.546 & 3.788 & \multirow[t]{2}{*}{-4.794} & \multirow[t]{2}{*}{$.005^{*}$} \\
\hline M4 & 66.93 & 0.642 & 1.574 & & \\
\hline M2 & 61.99 & 2.041 & 5.000 & \multirow[t]{2}{*}{-2.204} & \multirow[t]{2}{*}{$.079 * *$} \\
\hline M4 & 66.93 & 0.642 & 1.574 & & \\
\hline M3 & 61.66 & 1.050 & 2.572 & \multirow[t]{2}{*}{-5.370} & \multirow[t]{2}{*}{$.003 *$} \\
\hline M4 & 66.93 & 0.642 & 1.574 & & \\
\hline $5-\mathrm{C}$ & Mean & SEM & $S D$ & $t$-test & $p$ value \\
\hline M1 & 55.30 & 3.634 & 8.902 & \multirow[t]{2}{*}{-3.376} & \multirow[t]{2}{*}{$.020 *$} \\
\hline M4 & 68.10 & 2.804 & 6.869 & & \\
\hline M1 & 55.30 & 3.634 & 8.902 & \multirow[t]{2}{*}{-7.211} & \multirow[t]{2}{*}{$.001 *$} \\
\hline M5 & 65.79 & 2.537 & 6.215 & & \\
\hline M3 & 57.18 & 2.292 & 5.614 & -4.295 & $.008^{*}$ \\
\hline M4 & 68.10 & 2.804 & 6.869 & & \\
\hline M3 & 57.18 & 2.292 & 5.614 & -4.256 & $.008^{*}$ \\
\hline M5 & 65.79 & 2.537 & 6.215 & & \\
\hline
\end{tabular}

Mean - arithmetical mean / aritmetička sredina; SEM - standard error of arithmetic mean / standardna pogreška aritmetičke sredine; SD standard deviation / standardna devijacija; * significant difference of $5 \%$ / razlika značajna na razini od $5 \%$; ** significant difference of 10 $\%$ / razlika značajna na razini od $10 \%$; p - difference significance / značajnost razlike

Note / Napomena: Since the experiment included only 6 subjects, a milder significance criterion was applied i.e. $p<0.10$. / $S$ obzirom na to da je u eksperimentu sudjelovalo samo šest ispitanika, uveden je nešto blaži kriterij značajnosti, tj. p<0,10.

-3.43; $p=0.019$ ). Inside the M4 model seat, moisture content is significantly higher than in the seat of the M1 $(t=-4.79 ; p=0.005), \mathrm{M} 2(t=-2.20 ; p=0.079)$ and M3 $(t=$ $-5.37 ; p=0.003$ ). (III.) Moisture content between the lower extremities in the model M4 is significantly higher than in the models M1 $(t=-3.38 ; p=0.020)$ and M3 $(t=$ $-4.30 ; p=0.008)$, and in the model M5 where it is significantly higher than in the seats of $\mathrm{M} 1(t=-7.21 ; p=0,001)$ and M3 $(t=-4.26 ; p=0.008)$.

\section{CONCLUSION}

\section{ZAKLJUCAK}

Based on the study with six subjects and on the study results, the following may be concluded:

Surface temperature of a seat is always higher than its interior temperature. In this respect, the models with notched seats show smallest differences, which may lead to the conclusion that such seats are the smallest thermal insulators and, therefore, provide more 
comfortable sitting. A notch is relatively close to the observed areas and presumably provides better cooling of the padding materials.

Surface moisture on a seat is always lower than that inside the seat. Again, the least differences occur with the notched seats. In other words, notched seats have better vertical permeability and provide more comfort.

On the seat surface of the chairs with moulded PUfoam, the temperatures are higher than on other chairs. The same is with moisture, which develops on the bodyseat contact area. It is interesting to note that the seat, herewith referred to, is upholstered with Trevira ${ }^{\circledR} C S$ fabrics with some distinctive properties that may influence the feeling of warmth and humidity during sitting.

On a notched seat, the temperature between the lower extremities is below that on all other seat models.

From thermophysiological standpoint of seat comfort, the ideal seat may be a notched one. The least comfortable is that constructed of moulded PU-foam because of its closed structure, which prevents rapid air exchange from the inside of the material.

Measurements during the experiment have shown that the present equipment can determinate differences between temperatures and moisture. For moisture measurement it would be better if probes were smaller in order to achieve accurate measurements throughout the seat cross section. In other words, the problem was in probes size considering seat thickness.

We suggest further research into temperature and humidity of upholstery with different characteristics and composition of raw materials, different quality and properties of PU-foam upholstering and, definitely, with more subjects and samples.

\section{REFERENCES}

\section{LITERATURA}

1. Arens, E.; Zhang, H.; Huizenga, C., 2006: Partial- and whole-body thermal sensation and comfort - Part I: Uniform environmental conditions. Journal of Thermal Biology 31: 53-59 http://dx.doi.org/10.1016/j.jtherbio.2005.11.028.

2. Bartels, V.T., 2003: Thermal comfort of aeroplane seats: influence of different seat materials and the use of laboratory test methods, technical note. Applied Ergonomics 34: 393$399 \mathrm{http}: / / \mathrm{dx}$.doi.org/10.1016/S0003-6870(03)00058-9.

3. Cengiz, T.G.; Babalık, F.C., 2009: The effects of ramie blended car seat covers on thermal comfort during road trials. International Journal of Industrial Ergonomics 39: 287-294 http://dx.doi.org/10.1016/j.ergon.2008.12.002.

4. Grbac, I., 1988: Istraživanje kvalitete ležaja i poboljšanje njegove konstrukcije - disertacija. Sveučilište u Zagrebu, Sumarski fakultet, Zagreb.

5. Grbac, I.; Dalbelo Bašić, B., 1994: Thermal conductivity and moisture permeability in mattress. Drvna ind. 45 (4): 130-134.

6. Grbac, I.; Dalbelo-Bašić, B., 1996: Comparison of thermo-physiological properties of different mattress structures. Proceedings of the 18th international conference on Information technology interfaces, Pula, Croatia, June 18-21. University of Zagreb, University Computing Centre Zagreb, pp. 113-118.

7. Grbac, I.; Ivelić, Ž., 2005: Ojastučeni namještaj, Sveučilište u Zagrebu, Šumarski fakultet, Zagreb.
8. Grbac, I., 2006: Krevet i zdravlje. Sveučilište u Zagrebu, Šumarski fakultet, Zagreb.

9. Grbac, I.; Domljan, D., 2007: Namještaj i zdrav život, Sigurnost 49(3): 263-279.

10. Hänel, S.-E.; Dartman, T.; Shishoo, R., 1997: Measuring methods for comfort rating of seats and beds. International journal of Industrial Ergonomics 20: 163-172 http://dx.doi.org/10.1016/S0169-8141(96)00049-2.

11. Hedge, A.; Sakr, W.; Agarwal, A., 2005: Thermal effects on office productivity. Proceedings of the Human factors and ergonomics society 49th Annual meeting, pp. 823-827.

12. Ick, J.; Rothermel, H.M.; Hauptmann, H.G., 1976: The Application of Flexible Polyurethane Foam for Automotive Seating. Journal of Cellular Plastics 12: 177-181 http://dx.doi.org/10.1177/0021955X7601200307.

13. Kurz, B.; Diebschlag, W.; Heidinger, F., 1989: Recommendation for ergonomic and climatic physiological vehicle seat design. Journal of Cellular Plastics 25: 125-137 http://dx.doi.org/10.1177/0021955X8902500203.

14. Nicholson, G.P.; Scales, J.T.; Clark, R.P.; de CalcinaGoff, M.L., 1999: A method for determining the heat transfer and water vapour permeability of patient support systems. Medical Engineering \& Physics 21: 701-712 http://dx.doi.org/10.1016/S1350-4533(00)00003-5.

15. Qian, X.; Fan, J., 2006: Interactions of the surface heat and moisture transfer from the human body under varying climatic conditions and walking speeds. Applied Ergonomics 37: 685-693 http://dx.doi.org/10.1016/j.apergo.2006.01.002.

16. Raja, I.A.; Nicol, F., 1997: A technique for recording and analysis of postural changes associated with thermal comfort. Applied Ergonomics 28 (3): 221-225 http://dx.doi.org/10.1016/S0003-6870(96)00036-1.

17. Sakoi, T.; Tsuzuki, K.; Kato, S.; Ooka, R.; Song, D.; Zhu, S., 2007: Thermal comfort, skin temperature distribution, and sensible heat loss distribution in the sitting posture in various asymmetric radiant fields. Building and Environment 42(12): 3984-3999 http://dx.doi.org/10.1016/j.buildenv.2006.10.050.

18. Stumpf, B.; Chadwick, D.; Dowell, B., 2002: The Attributes of Thermal Comfort, Ergonomic criteria for the design of the Aeron ${ }^{\circledR}$ chair, Herman Miller Inc., U.S.A., www.hermanmiller.com

19. Vlaović, Z.; Konjuh, J.; Domljan, D., 2006: A study into the quality of the mattress cover fabrics. Proceedings of 16th international scientific conference: European Union - Challenges and perspectives for wood-processing industry, Zagreb, Croatia, October 14th 2006. Innovawood, UFI-Paris, University of Zagreb, Faculty of Forestry, pp. 101-106.

20. Vlaović, Z.; Bogner, A.; Grbac, I., 2008: Comfort Evaluation as the Example of Anthropotechnical Furniture Design. Coll. Antropol. 32(1): 277-283.

21. Vlaović, Z., 2009: Comfort factors of office chairs (Doctoral thesis, in Croatian). University of Zagreb, Faculty of Forestry, Zagreb.

22. Vlaović, Z.; Grbac, I.; Domljan, D.; Bublić, A., 2010: Office work chairs - research of deformations and comfort index (In Croatian). Drvna ind. 61(3): 159-168.

\section{Corresponding address:}

Assis. ZORAN VLAOVIĆ, Ph.D.

Department of Furniture and Wood Products

Faculty of Forestry, University of Zagreb

Svetošimunska 25, p.p. 422

HR-10002 Zagreb, CROATIA

e-mail: zvlaovic@sumfak.hr 